\title{
CRISTIANOS, MUDÉJARES Y MORISCOS EN EL MARQUESADO DE LLOMBAI
}

\author{
Elia GOZÁLBEZ ESTEVE
}

Universidad de Alicante

\begin{abstract}
Resumen
En el presente trabajo se aborda el análisis de los derechos devengados por los vasallos de un importante señorío valenciano como es el marquesado de Llombai, ubicado en la comarca de la Ribera Alta. En él se pasa revista a la importante relación de derechos que percibía el señor. Algunos de ellos difíciles de identificar y de cuyo origen y justificación se había perdido noticia; unos derechos que evidencian las grandes diferencias en la carga impositiva que soportaban los miembros de las dos comunidades que residían en el señorío: los cristianos y los mudéjares, moriscos tras su forzosa conversión. Tales diferencias, atribuidas en su origen a las de religión, subsistieron, sin embargo, cuando los mudéjares se vieron obligados a convertirse al cristianismo, generándose un sentimiento de discriminación entre los moriscos, pues las diferencias se mantuvieron -pese a algunas buenas palabras-, hasta su expulsión definitiva en 1609 .
\end{abstract}

\begin{abstract}
The analysis of the rights accrued by the subjects of an important señorio valenciano as is the Estate of Llombai is approached in the present work, and it is located in the region of the Ribera Alta. It examines closely the important relationship of rights that were perceivied by the Lord. Some to them are difficult to identify and of which the origins and proofs had been lost; some rights that illustrate the large differences in the tax loads that were sustained by the members of the two communities that were residing in the señorio: the Christians and the Mudejar, (Moorish after their mandatory conversion). Such differences, attributed originally to those of religion; subsisted, however, when the Mudejar were forced to be converted to christianity, generating a feeling of discrimination amongst by the Moorish, since the differences were maintained -in spite of some assurances-, until their definitive expulsion in 1609.
\end{abstract}

Es frecuente considerar la relevancia que tiene el señorío en el Reino de Valencia, puesto que numerosos trabajos sobre lugares bajo jurisdicción señorial, investigaciones parciales de algunos señoríos y más de una obra sistemática y rigurosa lo con- 
firman. Sin embargo, aún siguen siendo insuficientes los trabajos en los que se profundiza, analiza y desvela la interesante relación entre el señor y sus vasallos.

Indiscutiblemente, el tema resulta doblemente atractivo, cuando estos vasallos pertenecen a dos comunidades distintas como sucede en Llombai. Situado geográficamente al sudeste de la Ribera Alta, en una área eminentemente señorial y mudéjar, es de destacar su población mixta, ya que a pesar del amplio patrimonio que el duque de Gandía tenía en la zona, este hecho era infrecuente ${ }^{1}$.

Como ya sabemos, casi nada sucede por casualidad, y el emplazamiento de los mudéjares valencianos responde siempre a la situación de vencidos; por tanto, en el centro donde se ejerce una función administrativa, política o comercial en sus formas más complejas, hemos de encontrar siempre cristianos viejos ${ }^{2}$. Todas estas son las características que se dan cita en Llombai, centro administrativo alrededor del cual giraban los lugares de Catadau, Alfarp y Aledua con una población exclusivamente mudéjar.

A nuestro entender, las circunstancias que rodearon el marquesado (origen, ubicación, población mixta, etc.) además de darle una identidad propia, modélica en cuanto a su formación y desarrollo, sugiere varios temas de debate. En primer lugar, la posibilidad de analizar el trato del señor hacia sus vasallos de diferente credo; en segundo lugar, la relación, en el grado que la hubiese, entre estas dos comunidades; pero, sobre todo, la diferente tributación.

Pese a ser poco frecuente que la mezcla de las dos comunidades se diera en núcleos de población reducida, en Llombai, el escaso número de habitantes no fue un impedimento para que la universidad cristiana y la aljama mudéjar, más tarde morisca, compartieran un mismo espacio geográfico, aunque con diferentes intereses, lo cual, inevitablemente, contribuyó a su distanciamiento.

No sería razonable tomar una postura radical en cuanto a las diferencias de estos dos pueblos, que tantas cosas comunes tuvieron que compartir: «una misma época histórica, unas mismas estructuras económicas, semejantes técnicas agrícolas, hábitos comerciales,... $\gg^{3}$. Obviamente, hubo similitud, tal y como era de esperar; pero, también, existieron diferencias tan insalvables que ni siquiera la convivencia de siglos lograron neutralizar.

En el caso del marquesado de Llombai, a la ya compleja situación general, se unieron intencionalidades e intereses enmascarados, tanto por parte de su señor como de quien le representaba.

Absentista por excelencia, el duque de Gandía, se mostró ajeno e indiferente a la dualidad de estos dos pueblos, al estar más preocupado en conservar, y en muchos

1. GARCÍA MARTÍNEZ. S.: «La Ribera desde las germanías a la expulsión de los moriscos». Econonía Agraria i História local. I Assemblea d'Història de la Ribera, Institució Alfons el Magnànim, Valencia 1981, págs. 45-47.

2. HALPERIN DONGHI, T.: Un conflicto nacional moriscos y cristianos viejos en Valencia, Institución Alfonso el Magnánimo Diputación Provincial de Valencia, 1980, págs. 52-54.

3. CISCAR PALLARÉS, E.: La Valldigna siglos XVI y XVII. Cambio y continuidad en el campo valenciano. Diputació de València. Valencia, 1997, pág. 155. 
momentos en recuperar su patrimonio, que en intervenir en una compleja realidad social, la cual, en muchos aspectos, le era ventajosa.

En una adecuada comprensión de la evolución interna de los mudéjares valencianos, Halperin Donghi afirma que, sólo ocasionalmente, se confunden éstos con la población cristiana, como ocurre en Castilla, ya que aquí las comunidades mudéjares se hallan generalmente ubicadas cerca de un núcleo cristiano, añadiendo que, cuando ambas comunidades comparten un mismo poblado, la organización comunal es distinta ${ }^{4}$.

Para tratar este tema, son muy elocuentes las Tomas de Posesión del Marquesado. Por ejemplo: En el año 1511, en la Toma de Posesión de Doña Juana de Aragón, mujer de Don Juan de Borja, duque de Gandía, se convoca por separado «com es costum» a la universidad de cristianos de Llombai en la Iglesia y a la aljama mudéjar en la plaza de Llombai.

Como era previsible, el ritual del juramento de fidelidad y homenaje tampoco es el mismo para el justicia y jurados cristianos que para el alamín y jurados mudéjares; siendo, asimismo, diferente la forma de expresar el reconocimiento de autoridad y dominio del señor, ya que al margen de que unos juren sobre los Cuatro Evangelios y los otros, según la «çuna e xara» propia de su credo, el juramento de homenaje de los mudéjares era de «mans e de muscle» y el de los cristianos «de mans e de boca», ritual que acentúa y puntualiza que se trata de dos colectivos distintos. ${ }^{5}$

Vayamos por partes y detengámonos a considerar esta dualidad, en primer lugar, en el marco jurisdiccional y en los órganos de gobierno.

A grandes rasgos, debemos recordar que la administración de justicia dependía plenamente del señor aunque éste delegaba -ya desde finales del siglo XVI- en sus representantes más inmediatos. Como era de esperar, esta situación se agudizó al formar parte el señorío de la casa de Gandía.

De forma un tanto imprecisa, las fuentes señoriales, cuando se refieren a la universidad de Llombai, citan al justicia como el de mayor rango, protocolariamente seguido por dos jurados por comunidad y lugar, cuya misión era la de representarlos y defenderlos. Como otros cargos representativos en el señorío, podemos citar al «sequier», al «mustassaf», y al «mitsage».

Desgraciadamente, la documentación referente a la organización y administración local de la universidad de cristianos no es lo explícita que sería de desear y apenas trasluce la existencia de un «consell general» y de unos «consellers» convocados para la aceptación de las cartas de población, contratos agrarios y concordias, no haciendo referencia de su convocatoria, que nos conste, para tratar cuestiones referentes al común que excluyesen al señor ${ }^{6}$.

En los siglos XVI y XVII el marquesado sólo tenía un baile, obviamente residente en Llombai, el cual debió acumular algunas funciones por delegación del procurador general o por la fuerza de la costumbre. Su función más específica era la de

4. HALPERIN DONGHI, T.: Op. cit, pág. 52.

5. A.H.N.: Sección Osuna. Leg. 587 n $^{\circ}$ 6, Toma de Posesión año 1511.

6. A.H.N.: Sección Osuna. Leg. 1.028, Contratos agrarios, año 1444. Ibíd.: Leg. 587-78, Concordias. 
ser juez de todas las cuestiones suscitadas en torno a la explotación económica de la baronía. Como tal se hallaba presente en los alfarrazamientos, controlaba las rentas y regulaba los riegos; pero el baile, además, era el responsable de la gestión judicial concerniente a los mudéjares-moriscos?

Referencias aisladas, como su intervención reteniendo dinero a un morisco que se quería ir a Berbería ${ }^{8}$, el cobro de algunos guiages ${ }^{9}$ o la intervención del procurador para que se avisara al baile de que habían venido unos moros de Argel a Valencia y se tenía noticia de que iban a Llombai ${ }^{10}$, nos muestran su activa competencia en asuntos de mudéjares y moriscos $"$; pero, sobre todo, ponen de relieve el recelo y vigilancia a la que esta comunidad estaba sometida.

No siempre los bailes del señorío debieron ejercer su oficio con la diligencia debida. A mediados del siglo XVI el arrendatario acusa al baile Gabriel de Llanos de tener muchos descuidos, tales como que «los cristianos viejos no pagan luismos en lo que se pasa de moriscos a cristianos y no pagan sino diezmo y primicia.... ${ }^{12}$.

La cita interesa, lógicamente, no por las debilidades del baile sino porque se verifica su capacidad judicial respecto a los moriscos, y el control económico que ejercía sobre las rentas de los cristianos viejos.

La comunidad musulmana era representada por la aljama, organismo social-político-religioso que en Llombai, al igual que en los otros lugares del señorío, era portavoz ante el señor de las reivindicaciones de los mudéjares como colectivo, estando siempre presente en contratos y concordias.

Como principal administrador de cada aljama estaba el alamín, que presidía el consejo local y la rutina diaria de la comunidad. Había uno en cada aljama, y aunque garante y representante de la misma, no por ello, paradójicamente, dejaba de ser un excelente aliado y auxiliar del señor. Obviamente, esta actitud le era recompensada por el duque de Gandía en el marquesado, con dádivas y franquicias sobre sus bienes, con alusiones que hacen referencia directa al cargo que desempeñaba en términos inequívocos: «mija eretat del alamí com la deixa franqua per son ofici» ${ }^{13}$. Su actuación fue siempre como agente del baile, encargado de los impuestos, de las rentas y demás derechos señoriales. Sobre estas actuaciones, escuetamente, debemos mencionar que en el «memorial de los jornales que hicieron las aljamas al servicio del marqués» escritas en árabe «de má del alamí» se puntualiza que es el baile quien le paga en nombre del señor ${ }^{14}$.

\footnotetext{
7. A.H.N.: Sección Osuna. Leg. 587.

8. A.H.N.: Sección Osuna. Legs. 587 y 594/17.

9. A.H.N.: Sección Osuna. Leg. 594/17.

10. A.H.N.: Sección Osuna. Leg. 1.028.

11. A.H.N.: Sección Osuna. Leg. 587.

12. A.H.N.: Sección Osuna. Leg. 594/17, año 1541.

13. A.H.N.: Sección Osuna. Leg. 1.028, año 1444.

14. BURNS, R.I: Colonialisme Medieval. Explotació postcroada de la Valencia Islàmica, Tres i quatre. Biblioteca d'Estudis i Investigacions, Valencia 1987, págs. 327-331. A.H.N.: Sección Osuna. Leg. $587 / 53$.
} 
Pero no sólo la documentación deja entrever las funciones del alamín como agente señorial sino que, además, nos lo presenta como intermediario, supervisor y recaudador, matizando en algún período su solvencia, ya que es él quien en épocas de crisis presta la simiente, «forment», tanto a los mudéjares como a los cristianos, legando a adelantar al señor, concretamente en 1403, «veintinou cahises de forment per a casa del senyor» ${ }^{15}$.

En cuanto al alfaquí, dada su función religiosa, desaparece con la conversión, y la documentación señorial apenas recoge su actuación; tan sólo, aisladamente, se cita su casa como lugar de reunión de la aljama ${ }^{16}$.

Respecto a los jurados mudéjares del señorío, desempeñaron funciones muy similares a las de sus homólogos cristianos, tanto en los consejos como ratificando las decisiones acordadas por la comunidad ${ }^{17}$.

Algunas referencias esporádicas indican que, a los jurados moriscos, se les dio mayor relevancia y representatividad en las cuestiones de interés señorial, con la intención de congraciarse con la comunidad teóricamente asimilada. Sirva como ejemplo, que al requerir su presencia para justipreciar ciertas tierras de Alfarp que quería el señor para plantar viña ordena que sean alfarrazadas «Per lo batle y per lo col.lector y per mi, y per dos jurats de Llombay lo hu cristià vell e lo altre moro segons a manat la senyoria se faja» ${ }^{18}$.

Cabe añadir que después de la reconquista la sociedad mudéjar quedó como una sociedad superviviente a la que los acontecimientos históricos distorsionaron su organización político-social, pero en la que pervivió la aljama y consejo de viejos ${ }^{10}$. En este sentido, es de destacar que, al principio, los mudéjares gozaron de mayor autonomía en la organización de sus aljamas y en la elección de los cargos municipales ${ }^{20}$. Con todo, progresivamente, los señores cristianos equipararon sus funciones y organización administrativa con las del consejo de cristianos; el sistema, los funcionarios y sus atribuciones eran análogas, sólo cambiaron, a lo sumo, de nombre.

Con esta breve síntesis, sólo pretendemos poner de relieve la significación de la administración local en las comunidades de Llombai, con la evidente dificultad de discernir con precisión su función y alcance, comprobamos que la divisoria que separaba ambas administraciones siempre estuvo presente y que la aljama, sistemáticamente, fue mediatizada por el titular del lugar, por sus representantes y, en general, por los

15. A.H.N.: Sección Osuna. Leg. 587, año 1403. Ibíd.: Leg. 1.027/42.

16. A.H.N.: Seccion Osuna. Legs. 1.028 y $587 / 18$.

17. A.H.N.: Sección Osuna. Leg. 587/259 y Leg. 587-594. Los jurados del marquesado en 1541 presionan al arrendatario para que conserve las regalías en buen estado, amenazando con recurrir a sus superiores, gobernador o duque. FERNÁNDEZ GIMÉNEZ. I.: «Los mudéjares del condado de Ricla». $V$ Simposio Internacional de mudejarismo. Instituto de Estudios Turolenses, Teruel 1991, pág. 39.

18. A.H.N.: Sección Osuna. Leg. 587. Lista de Gastos del arrendatario Melchor Martínez. año 1542. CISCAR PALLARÉS. E.: La Valldigna siglos XV y XVII..., pág. 256.

19. FEBRER ROMAGUERA, M.V.: «Antecedentes y configuración de los consejos de viejos en las aljamas de moros valencianos». V Simposio..., págs. 160 a 169.

20. GUAL CAMARENA, M.: Las Cartas Pueblas del Reino de Valencia. Edición a cargo de Desamparados Pérez Pérez. Generalidad Valenciana, Valencia, 1989, pág. 65. 
cargos directivos de la universidad cristiana, situándola, inexorablemente, en una posición de inferioridad. Coyuntura que experimentó muy pocos cambios después de la forzosa conversión. A nivel administrativo la innovación más significativa fue, posiblemente, el nombramiento de un justicia en cada una de las comunidades moriscas.

Otro cargo muy importante dentro del marquesado fue el del arrendatario. Su importancia radicaba en el absentismo del titular del lugar, el cual delegaba ampliamente la gestión económica del señorío. Por regla general, los contratos de arrendamiento insisten en que el arrendatario no precisa de otra autoridad más que de la suya, sin que tenga que recurrir a ningún oficial señorial para imponer justicia y vigilancia, tanto en el monte como en la huerta ${ }^{21}$. Es de suponer que al menos en algún momento del siglo XIV éste fuese un mudéjar, o con mayor seguridad, la aljama. A este respecto, podemos citar que el Contrato Agrario de 1401 entre D. Aymerich de Centelles y sus vasallos de Catadau recuerda la anulación de un anterior arriendo del lugar a la aljama, concretamente en tiempo de Ramón Castelló ${ }^{22}$.

No es cuestión de entrar en detalles, pero durante el siglo XVI nos consta que los arrendatarios eran cristianos viejos procedentes casi siempre de una esfera social determinada: comerciantes y mercaderes provenientes de Valencia o Gandía que veían en esta gestión una buena ocasión para enriquecerse, tal y como lo confirman los arrendamientos analizados en el marquesado en este periodo ${ }^{23}$.

Al margen de otras cuestiones, la condición económica de los mudéjares-moriscos del marquesado no les permitía arrendar globalmente el señorío, aunque sí algunos derechos por separado como las regalías o los diezmos, arrendados regularmente a moriscos del señorío hasta principios del siglo XVII ${ }^{24}$.

Las consideraciones hasta aquí vertidas evidencian la divergencia existente entre estas dos comunidades, quedando de manifiesto siempre cuál era la sometida, agudizándose esta diferenciación de forma definitiva en la fiscalidad.

No debemos olvidar que la «Foia» y Baronía de Llombai era un núcleo mudéjar con una pequeña minoría cristiana que aprovechó su privilegiada posición para quedar libre de algunos impuestos, dando lugar a una plural y compleja tributación cuya interpretación y aceptación dio lugar a que se dieran tres situaciones de hecho sumamente interesantes:

\section{TRIBUTOS COMUNES PARA CRISTIANOS Y MUDÉJARES}

El titular del señorío ejercía su jurisdicción civil y criminal, mero y mixto imperio sobre todos sus vasallos con independencia de su credo; por tanto los ingresos provenientes de la participación del señor en «penas y composiciones» afectaban por igual a ambas comunidades.

21. A.H.N.: Sección Osuna. Leg. 588. Arrendamiento, año 1575. Ibíd.: Leg. 1.027. Arrendamiento, año 1607.

22. A.H.N.: Sección Osuna. Leg. 722/6. Contrato agrario, año 1401.

23. A.H.N.: Sección Osuna. Leg. 583/32. Ibíd.: Leg. 588/4/5. Arrendamientos de los años 1540 a 1545.

24. A.H.N.: Sección Osuna. Leg. 562. En el periodo 1603 a 1606 se arriendan los diezmos de Llombai a Joan Turixi. Ibíd. Leg 937/3. Año 1540 «la almasera de fer l'oli ters delme y part del senyer es arrendada a Albaydal Palletes vehi de Catadau per trenta arroves de olis. 
De este ingreso destaca su escasa importancia; con todo, su variabilidad lleva a que en algún año, como en 1542 -año muy conflictivo como más adelante tendremos ocasión de comprobar- las penas y composiciones supongan el $8 \%$ de las rentas, lo cual no era despreciable, sobre todo en un señorío con una renta agraria considerable ${ }^{2.5}$.

Asimismo, el señor, por su condición, recibe regalos navideños: «las adehalas», con aportaciones diferentes según la comunidad. Los cristianos viejos entregaban gallinas; y los mudéjares, miel, palmitos y gallinas. La contribución de la comunidad de origen islámico fue objeto de mayor interés y preocupación por parte de la administración señorial como se expresa en una extensa relación del año 1538, en la que la calidad y cantidad entregada es motivo de queja y de una minuciosa investigación ${ }^{2 \hbar}$.

El titular, por esa misma naturaleza «de señor», también tiene derecho al tercio diezmo, a las regalías y a los servicios personales. Ya en las relaciones de las rentas del XV insistentemente se repite que los vasallos de los cuatro lugares deben satisfacer a su señor el tercio diezmo: «Ha lo senyor lo ters del delme de la panca o de la figua e de la garrofa e de tots altres explets de cristians com de moros» (Llombai) ${ }^{27}$.

Curiosamente, el sistema de recaudación del tercio diezmo, en una población mixta como es la que aquí nos ocupa, está más generalizado que las particiones. La prueba de que esta fiscalidad atañe a las dos comunidades nos lo confirman, reiteradamente, las relaciones de rentas de este período, en términos iguales o muy semejantes a los que siguen: «ha poçeit de forment en Llombay axi de ters delme dels cristians vells com no paguen part alguna perque axí lo diu lo col.lector y també per lo ters delme dels moriscats y per la part del senyor dels moriscats» «ha poceit dactza en Llombay en lo presente any axí del ters delme dels cristians vells com del terç delme dels moriscats» «ha lo senyor lo terç delme del carnage axi dels cristians com de moros» ${ }^{2 x}$.

De igual forma, los monopolios señoriales afectaban por igual a la universidad que a la aljama, tanto los procedentes de la manufactura rural de transformaciones agrarias e industriales, como los servicios de la comunidad. Sobre los últimos, conviene tener en cuenta que el mesón o el hostal, por el control que el tránsito de forasteros exigía, siempre estuvo ubicado en Llombai y que cada comunidad tenía su carnicería propia debido a las diferencias alimenticias, religiosas y rituales ${ }^{20}$.

Con los datos disponibles, parece deducirse que ambas comunidades tenían una común obligación con el canon enfitéutico; pero, concretamente, en lo referente a

25. A.H.N.: Sección Osuna. Leg. 937. Renta del año 1542. GOZÁLBEZ ESTEVE, E.: Análisis de un señorio valenciano: El marquesado de Llombai. Tesis Doctoral inédita. Universidad de Alicante, Alicante, año 1990 , pág. 25.

26. A.H.N.: Sección Osuncr. Leg. 587/17. «Lo que las aljamas tenían que dar al señor por Navidad».

27. A.H.N.: Sección Osuna. Leg. 1.028.

28. A.H.N.: Sección Osuna. Leg. 937. Rentas de los años 1540-1541-1542. Ibíc.: Leg. 1.027/21. La casa de Gandía percibía el tercio diezmo en muchos de sus lugares, como en Castellón de Rugat, Chella, Turis...

29. A.H.N.: Sección Osuna. Leg. 1.028. Fecha aproximada 1444. En el siglo XV había tabernas en los cuatro lugares del marquesado. Hecho curioso ya que se trata de comunidades mudéjares. y además no se pueden confundir en este caso taberna con tienda, puesto que esta última también estaba arrendada durante este periodo. 
peitas o magram, este señorío ofrece una variedad difícilmente reducible a unas líneas básicas. Aquí, simplemente, nos limitaremos a traer a colación algunos aspectos, sin entrar en la polémica suscitada por Burns referente a la confusión que puede haber entre peita y magram ${ }^{30}$. Lo que ahora nos interesa es destacar bajo qué término se satisfacía este impuesto y qué realidades lo componían. En las rentas de 1403 se precisa que los cristianos pagan peita y los mudéjares, magram $^{31}$; mientras que en la relación de las rentas del XVI se califica el magram como peita de moros unificando estas dos denominaciones ${ }^{32}$.

El término magram, a finales del XVI, había perdido totalmente su significado fiscal sobre tierras de huertas para pasar a ser un censo global de casas y tierras sin distinguir la calidad de las mismas. «Per lo magram o peita que pagan los moriscos ço es, per les cases e terres dels moros» ${ }^{33}$.

Conocemos lo que pagaban los cristianos por casa y tierras; « 4 sueldos 6 diners por casa y I sueldo 4 diners per faneçada de terra" pero no la cantidad que afectaba a los mudéjares-moriscos. Globalmente, la peita de los cristianos del marquesado era más elevada e inamovible que la de los mudéjares, «ni puja ni devalla», sin que podamos determinar qué conceptos la integraban, si era porque tenían más propiedades $o$, sencillamente, porque la tasación era diferente en compensación hacia el señor por alguna exención ${ }^{34}$.

Lo que sí parece estar bastante claro es que, en los siglos XV y XVI, ambas comunidades pagaban peita o magram por casas y tierras denominándose en muchas ocasiones, estrictamente, como peita ordinaria. «paguen los de Aledua cada any al senyor de peita ordinària de les cazes y heretats y vinyes que no munta ni devalla» ${ }^{35}$.

\section{TRIBUTOS QUE AFECTABAN A LAS DOS COMUNIDADES SÓLO EN TEORÍA}

Dado que la partición de frutos representa en este señorío el ingreso más importante de la renta señorial y aunque no vamos a precisar aquí ni su cuantía ni los productos sujetos a partición, sí que debemos mencionar que no todos los lugares que formaban el señorío estaban gravados por igual, detectándose una sensible reducción

30. BURNS, R. I.: Colonialisme ..., pág. 143.

31. A.H.N.: Sección Osuna. Leg. 102-104 y Leg. 588/2.

32. A.H.N.: Sección Osuna. Leg. 586 «Per magran o peita ordinària de Aleduct». LÓPEZ DE COCA CASTANER, J.E.: «La fiscalidad mudéjar en el reino de Granada». V Simposio..., págs. 192 a 218.

33. CISCAR PALLARÉS, E.: Tierra y Señorío en el País Valenciano (1570-1620). Del Cenia al Segura, Valencia, año 1977. pág. 101. Del mismo autor La Valldigna..., págs. 191-192. A.H.N.: Sección Osuna. Leg. 586.

34. A.H.N.: Sección Osuna. Leg. 102/4. Renta 1403. Ibíd.: Leg. 586. Ibíd.: Leg. 937. Rentas del año 1534. BENÍTEZ SÁNCHEZ-BLANCO, R.: «Benimamet: un baronía de la huerta de Valencia a fines del XVI». V Simposio... Dicho autor afirma que el censo de cristianos era la suma del morabatín del censo ordinario y de la conversión en dinero de azofras y servicios, págs. 255 a 263. CISCAR PALLARÉS, E.: Tierra y Señorio..., «Peita $111 / 1.17$ sueldos y dineros per la peita que Los cristianos pagen co es 4 sueldos 6 dineros por cada e 1 sueldo 9 dineros per fanecada de terra la cual peita ni puja ni devalla », pág. 102

35. A.H.N. Sección Osuna. Leg. 937. Renta del año 1540. Ibíd.: Leg. 586/10. Renta del año 1538. 
en las particiones en Llombai y Catadau respecto a Alfarp y Aledua. Predominando en los primeros la partición de un cuarto en la huerta y un octavo en la montaña, atendiendo a la calidad de las tierras; mientras que en Alfarp y Aledua tenían, en la totalidad de los productos cultivados, la onerosa partición de la tercera parte en la huerta, con alguna excepción como en el Rahal que partían a la cuarta parte.

Es de suponer que este derecho afectase, por igual, a las dos comunidades; o, todo lo más, que en algún momento -como sucedía en la vecina Carlet- los cristianos tuviesen algunas condiciones más favorables ${ }^{36}$. Sin embargo, pese a que la documentación manejada no hace ni la más leve insinuación de que los cristianos viejos estuviesen exentos de partir sus cosechas con el señor, y sí muchas de su obligatoriedad, no la cumplían.

Sirva de ejemplo la insistencia con la que el arrendatario del marquesado denuncia dicha situación, quejándose de que los cristianos viejos no estaban sujetos de partir los productos agrícolas con sus señores, si no de derecho sí al menos de hecho, sin ningún tipo de justificación: «Ha poçeit de forment en Llombay axí de ters delme dels cristians vells com ells no paguen part alguna perquè axí lo diu lo col.lectorn ${ }^{37}$.

Enmarcados dentro de un status social inferior, sólo los mudéjares, más tarde moriscos, pagan laudemio en el señorío. Con claridad, las citadas rentas del XVI se hacen eco de esta condición escribiendo la palabra luismo en árabe, para que no hubiese ninguna duda de a quién iba dirigida la imposición, puntualizando con frases tan directas como: «per lo luïsmes de les cases y heretats que se són venudes lo present any en tot lo marquesat per lo moriscos com diu lo collector que los cristians vells no paguen» ${ }^{38}$.

Esta confusa situación dio lugar a que se redactase un memorial dirigido a Don Francisco de Borja, cuyo contenido encierra «una memoria de las dudas que se propusieron al señor sobre los derechos que deben pagar los vasallos cristianos y moros de este marquesado respecto de la participación de los luismos» ${ }^{39}$.

Como primera queja se notificó al señor que los cristianos viejos se negaban a pagar luismos, argumentando, simplemente, que nunca lo habían hecho, lo cual, obviamente, no aclaraba la cuestión. Así dicen textualmente que desconocen «si fue gracia antiga por ser christianos o por grangería holgado los señores que los cristianos vendieren y comprassen los moros por augmento de sus rentas» ${ }^{40}$. Actitud muy generalizada que, forzosamente, frenaba las ventas de los mudéjares a los cristianos en todo el reino de Valencia.

Obviamente, al permitir los señores que los cristianos no pagasen luismos, estaban, en última instancia, favoreciendo sus intereses, ya que así, facilitaban que los cristianos vendiesen; engrosando, con ello las haciendas de los mudéjares, sujetos a mayores censos y particiones.

36. BENÍTEZ SÁNCHEZ-BLANCO, R.: «Las cartas pueblas del condado de Carlet y los conflictos sobre sus aplicaciones». Saitabi XXXXVI, Valencia, año 1986, pág. 191.

37. A.H.N.: Sección Osuna. Leg. 937-3, año 1540. Ibíd.: Leg. 594/17, año 1541.

38. A.H.N.: Sección Osuna. Leg. 594/17.

39. A.H.N.: Sección Osuna. Leg. 594/17.

40. A.H.N.: Sección Osuna. leg. 594/17. 
La segunda duda planteada en este memorial evidencia la resistencia, cada vez más persistente de los moriscos, a satisfacer esta carga, pretendiendo no pagar cuando «baratan o truecan una heredad con otra, o en caso de donación graciosa».

A lo que se les respondió que debían pagar siempre que no presentasen justificantes de gracias, privilegios o en casos de dotes y testamentos, por ser transacciones consideradas privilegiadas y libres de toda carga, matizando que en casos de trueque debían pagar sólo la diferencia de lo que vale una heredad más que la otra ${ }^{41}$.

Los cristianos viejos tampoco quedaron al margen de este intento revitalizador de los luismos. El arrendatario, con la esperanza de hacer cumplir este derecho derivado de la enfiteusis, insiste en dicho memorial en que los cristianos, igualmente, pagasen luismos, aunque sin ningún éxito ${ }^{42}$.

Dentro de este contexto, debemos recordar que los nuevos convertidos, a lo largo y ancho del reino, exigieron de forma reiterada ser considerados como los demás cristianos, a lo que se les respondió, también reiterativamente, con negativas, imprecisión y descarga de responsabilidades.

Del conjunto de la información disponible, parece deducirse que el laudemio fue en el señorío tema trascendente y conflictivo. Laudemios onerosos y diferenciados en cuanto a la calidad de lo enajenado en el siglo XV, alcanzaron en el lugar de Alfarp cantidades tan elevadas como la tercera parte, semejantes a los foriscapios catalanes. Derecho señorial muy interesante en el que no podemos profundizar ya que lo que aquí nos proponemos es, principalmente, dilucidar si hubo una discriminación fiscal, real o teórica entre estas dos comunidades, sin que ello implique, en ningún momento, ponderar el gravamen a que estaban sujetos los mudéjares-moriscos.

\section{TRIBUTOS QUE AFECTABAN SÓLO A LOS MUDÉJARES}

Como era de prever, los señores del marquesado se esforzaron en mantener sobre sus vasallos mudéjares una serie de derechos de tipo musulmán, como la alcaidía, «la alfatra», el morabatín y el derecho de herencias.

La alcaidía era un derecho satisfecho desde antiguo por los mudéjares de la «foia» y Baronía de Llombai por heredad, cocretamente en Catadau con «Huna fanecada de forment a rras. E sis ven alguna heretat ab casa sis sous per alcaydya». Y en el contrato agrario de 1444 (fecha aproximada), también de Catadau, se especifica que el derecho de alcaidía era satisfecho «per los moros» con una «fanecada de forment, una gavilla de lli» y un «terraç, que es lo quint de una rrova» de aceite, añadiendo «si vendra ningun moro heretat ab casa ultra lo loisme pagua sis sous de alcaydya e sis vendra sens casa tres sous».

La incorporación al derecho de alcaidía de seis sueldos provinientes de ventas conjuntas de casa y heredad, puede tener su origen en la fadiga en compensación a la

41. A.H.N.: Sección Osuna. Leg. 594/17. Memorial del año 1541, cap.IX.

42. BENÍTEZ SÁNCHEZ-BLANCO, R.: «Las cartas pueblas del Condado de Carlet...». Señala este autor que cada comunidad tenía sus características, añadiendo que: «Mientras que el mudéjar paga en concepto de luismo una cuarta parte del precio, salvo en caso de donación por matrimonio, que no paga nada, los cristianos pagan medio luismo», pág. 190. 
renuncia de ejercer los derechos de tanteo y retracto. Es posible que quedase anejo al cargo del alcaide, por ser este el encargado, en otro tiempo, de otorgar la fadigas, como máximo representante del señor en Llombai.

En los otros lugares del señorío, el impuesto obliga a entregar «oly de aquell el que.n cullira un terras de quint de arroba» y «aquell qui cullira lli en la heretat sia tengut pagar e donar al señor una garba del dit lli».

Sin lugar a duda, lo más interesante de este derecho es la aportación en metálico con que se grava el lugar de Catadau por ventas, en estrecha relación con la fadiga.

Al igual que otras aportaciones en especie, la alcaidía se trasformó en un precio global, obligando exclusivamente a los moriscos «per dret de alcaydya per les XXXI heretats morisques cinch lliures, $X V$ sous».

No está de más resaltar el importante papel de las aljamas del señorío en el siglo $\mathrm{XV}$, las cuales, garantes de cualquier pérdida, se comprometen a pagar la alcaidía por los mudéjares que no lo hicieran, con la consecuente seguridad que esto suponía para el señor ${ }^{43}$.

En cuanto al «dret de fatras», «alfitra» o «satera» se caracterizó por su universalidad entre los mudéjares, obligándoles a entregar al señor «cascun cap per dret de fatra en almut de panis a corrent ${ }^{44} \sin$ límites de edad como sí ocurre en otros lugares valencianos, por ejemplo, en Cheste y Carlet ${ }^{45}$. Este tributo relacionado con el «alfaquinatge», en su origen debió servir para sostener al alfaquí, pasando después de la reconquista a formar parte de los derechos del titular del señorío, el cual lo mantuvo, de forma discriminatoria y obsoleta, aún después de la conversión.

Respecto al morabatín desconocemos por qué en el marquesado afectó sólo a los mudéjares; pero la relación de rentas del siglo XVI nos trasmite este hecho con notas tan explícitas como la siguiente: «cascun moro per cascuna casa un sou, son vent $i$ cuatre cases les que paguen morabatin y les altres paguen IIII sous per casa XXIIII litures ${ }^{46}$.

Las obligaciones fiscales, aunque no siempre rentables, fueron muchas. Los señores de la «foia» y baronía de Llombai estaban también interesados en participar de las herencias de sus vasallos mudéjares, al igual que el rey en el realengo ${ }^{47}$, no obstante en ambos casos existían notables diferencias.

43. A.H.N.: Sección Osuna. Legs. 722, 937 y 1.028. GOZÁLBEZ ESTEVE, E.: Análisis de un señorio..., pag. 157. CISCAR PALLARÉS, E.: La Vallidgna..., pág. 204.

44. A.H.N.: Sección Osuna. Legs. 1.028 y 937. Ibíd.: Leg. 586. Renta del año 1542.

45. BENÍTEZ SÁNCHEZ-BLANCO, R.: «Las cartas pueblas...». Cap. 38, «pagan este derecho todos los mudéjares sin limites de edad», pág. 207. RISALA-FIL-FIGH.: Compendio de Derecho Islámico. IBN-ABI ZAIYD. AL-GAYWANI. Edición de Jesús Riojales. Ed. TROTTA. 1993.

46. A.H.N.: Sección Osuna. Leg. 1.028. Ibíd.: Leg. 586. Relación de la renta de Llombai en el año 1534. GUAL CAMARENA, M.: Las cartas pueblas.... pág. 70.

47. A.H.N.: Sección Osuna. Leg. 1.028. Ibíd.: Leg. 589/259, año 1538. Ibíd.: Leg. 937, años 1539 a 1554. Ibíd.: Leg. 586, año 1534. GUINOT RODRÍGUEZ, E.: Cartes de poblament Valencianes. Año 1405. Generalitat Valenciana. Valencia, año 1991. pág. 653. GARCÍA ARANCÓN, R.: «Algunas precisiones sobre la fiscalidad de los mudéjares navarros». $V$ Simposio..., pág. 246. LÓPEZ DE COCA, CASTAÑER, L. E.: «La fiscalidad mudéjar en el reino de Granada» V Simposio ..., pág. 196. 
Tanto en el siglo XV como en el XVI, las relaciones de las rentas citan este derecho señorial sin explicar su contenido con frases tan escuetas como: «a lo senyor dret de herències» o tan confusas como «les herències o dret de aquelles si emperò les dites herències los dits moriscats seran obligats a pagar e no en altra manera» ${ }^{48}$.

Dentro de esta compleja y variada fiscalidad, el dueño directo del señorío aprovecha cualquier situación que beneficie sus ingresos. En este sentido, es curioso advertir cómo se adueña y arrienda puntual y repetitivamente los servicios más usuales de la comunidad mudéjar como el baño, la almaxita, las colmenas y la caza de las perdices, a sus vasallos de origen islámico. En cuanto al primero, nos consta la existencia, al menos, de un baño en el siglo $\mathrm{XV}$, propiedad del señor y sujeto a arrendamiento, desapareciendo a comienzos del XVI (aproximadamente 1514) tal y como lo denuncia la nota siguiente: «no $i$ a bany que lo senyor lo dona als christians per fer ne casa ${ }^{49}$.

La importancia de este hecho no debe pasar desapercibida dado que las comunidades islámicas consideran el baño como un signo de identidad cultural, tanto su explotación como su eliminación por parte del señor, supone un trasfondo digno de tenerse muy en cuenta.

Asimismo los mudéjares de los cuatro lugares pagaban, en concepto de arrendamiento, una cuota anual por el derecho de disponer de partera propia, bajo la denominación de almaxita, beneficiándose el señor, una vez más, de las diferencias culturales de sus vasallos mudéjares ${ }^{50}$.

Desde antiguo, se arrendó en el señorío las colmenas, la «mel cocha», y la caza -concretamente la de las perdices- generalmente a los mudéjares, debido, entre otras razones, a su habilidad en la crianza y caza de animales; sin descartar, la necesidad que estos vasallos debían de tener de rentas complementarias a su precaria economía doméstica ${ }^{51}$.

A esto, hay que añadir que el señor tenía otros derechos de carácter agrario de escasa relevancia, satisfechos en especie, que habían sido igualados en dinero mediante concordias o avenencias tales como «el dret de fulla», «dret de alfals», «dret de vinya», «dret de lli», «terra de perayres», pero la documentación en ningún momento señala a qué colectivo afectaba; por tanto, no vamos a hacer ningún comentario sobre ellos.

Por último, las azofras originarias del derecho islámico, constituyen la parte que mejor refleja esa discriminación a la que, insistentemente, nos estamos refiriendo.

48. Pla ALBEROLA, P.: Conflictos jurisdiccionales en un gran señorio Valenciano. El condado de Cocentaina ante la consolidación del absolutismo. Tesis doctoral inédita Universidad de Alicante. Alicante 1985, pags. 630-633. Del mismo autor: «Rentas señoriales del condado de Cocentaina en vísperas de la expulsión» $V$ Simposio..., pág. 280. HINOJOSA MONTALVO, $\boldsymbol{J}$.: «Señorío y fiscalidad mudéjar en el Reino de Valencia». V Simposio... Hace constar la vigencia de este derecho en el siglo XV calificándolo de carga onerosa, de la cual el mudéjar tratará de liberarse, pág. 128.

49. A.H.N.: Sección Osuna. Leg. 1.028. Nota al márgen fechada en 1514.

50. A.H.N.: Sección Osuna. Leg. 1.028. Año aproximado 1444. Contratos agrarios.

51. A.H.N.: Sección Osuna. Leg. 1.028. Ibíd.: Leg. 937 «la casa arrendat». Año 1542. Ibíd.: Leg. 1.027. Año 1560. «Per la arrendament de la casera». Ibíd.: Leg. 1588. En el año 1539 se arrendó la caza de las perdices a el morisco Mahomet. 
Aunque aceptemos que las azofras responden a una situación anterior, no hay duda de que fueron aprovechadas por los señores, con los cambios que representa el pasar de ser un tributo público a una exigencia señorial.

Las azofras, importante rasgo diferenciador entre estas dos comunidades, afectaron exclusivamente a los mudéjares-moriscos, mientras que los cristianos permanecieron exentos de ellas como tales, aunque no de algunas prestaciones personales.

En el marquesado las azofras más significativas fueron los siguientes:

\section{a) El mantenimiento de las fortificaciones}

Este obligaba a los mudéjares con una serie de jornales gratuitos «tantos como quisiera el señor $>$ para la construcción y mantenimiento de murallas, castillo o casa señorial, bajo disposiciones tan tajantes como la que sigue: «Si lo senyor volrà obrar en lo castel sòn tenguts los dits moros de dar li tans jornals com mester haurà, axi ab bèsties com sens bèsties franchs» (Llombai) ${ }^{\mathrm{s}_{2}}$. Comprometiéndoles, además, a avituallar el castillo o casa del señor con leña, siempre y cuando estuviese su titular en el lugar ${ }^{53}$.

\section{b) La gratuidad del transporte de los productos agrícolas}

Pese a que no se especifica con claridad que los cristianos viejos estuviesen exentos, lo que sí es cierto es que como tal azofra no les afectaba. La documentación es tan explícita en los contratos agrarios de mediados del siglo XVI como para precisar a quién afecta en Llombai en los siguientes términos: «sòn tenguts los moros de portar tots los blats, esplets e altres coses de lurs drets quatre o chinch llegües entorn franch ${ }^{54}$

\section{c) Tandas de jornales}

Tanto los jornales gratuitos como los remunerados, siempre obligatorios, interesaron a los señores del marquesado de forma muy especial, sin embargo, este interés fue decreciendo cuando sus tierras en el señorío disminuyeron y su absentismo se hizo más patente. Los gratuitos concernían, exclusivamente, a los mudéjares-moriscos, mientras que los remunerados, aunque de diferente forma, afectaban a las dos comunidades. A mediados del siglo XV, el señor se reserva tres jornales francos de sus vasallos mudéjares para la viña en Llombai y Catadau, uno en Alfarp «son tenguts de veremar e tirar la verema e calçigar e lavar gerres e portar lo vi a Valençia o quatre llegues en torn tot franch», además se especifica que «son tenguts los moros, si lo senyor volrra fer laurada, de fer al senyor jovada axi que li layuraran un jornal per heretat e a segar altre jornal cascun any una vegada franch al senyor», y siete en

52. A.H.N.: Sección Osuna. Leg. 1.028. Contratos agrarios. GOZÁLBEZ ESTEVE, E.: «Las azofras en e] marquesado de Llombai». Señorio y feudalismo en la península ibérica, SS. XII-XIX. Institución Fernando el Católico. Exma. Diputación de Zaragoza. Vol. III, Zaragoza, año 1993. pág 141. GUICHARD, P.: «Le probleme de la azofra dans le Royane de Valence au XIIle siecle». Madrid, año 1972. pág. 67.

53. A.H.N.: Sección Osuna. Leg. 937/3, años 1540 a 1544. Ibíd.: Leg. 1.027, año 1563.

54. A.H.N.: Sección Osuna. Leg. 1.028. Contratos agrarios, fecha aproximada 1444. GOZÁLBEZ ESTEVE, E.: «Las azofras...», pág. 345. BENÍTEZ SÁNCHEZ-BLANCO, R.: «Las cartas pueblas...», págs. 189 a 191 . 
Aledua, «son tenguts a cavar set jornals per heretat o a fer ço que lo senyor ne volrra cascun any una vegada», siendo conmutados mediante concordia en el siglo XVI a un pago en metálico.

En cuanto a los jornales remunerados tenían una variada gama de precios según a qué fuesen dedicados, diferenciando si los realizaba un hombre solo o con su cabalgadura: «Sòn tenguts que si lo senyor volrrà tans jornals com li plaurà, e a quina faena volrrà anat a tanda fer los dits jornals donant lo senyor un sou per jornal a ome forro o un real de Valencia ab cavalgadura ${ }^{55}$.

El deterioro de la costumbre, la poca diligencia de los subordinados señoriales y las continuas demandas de las aljamas tendentes a reducir estas prestaciones, dieron lugar a sucesivas concordias; sin olvidar, el interés señorial en aumentar los ingresos en metálico en sustitución de unos servicios personales que le eran ya innecesarios ${ }^{56}$.

d) Hilaza

El único trabajo textil que se mantuvo desde antiguo como servidumbre de los mudéjares del señorío era hilar para el señor una cierta cantidad anual de lino o estopa, sin precisar si obligaba a los hombres o a las mujeres como sucedía, por ejemplo, en Carlet ${ }^{57}$. Esta azofra tenía muy poca oscilación en cuanto a su aportación de unos lugares a otros, conmutada también en metálico a principios del siglo XVI, presentaba la peculiaridad de que obligaba también a los xamesos, en compensación hacia su señor por no tener tierras ni casas, lo cual les eximía de otras obligaciones tributarias ${ }^{58}$.

\section{e) Suministro a la despensa señorial}

Dentro del capítulo de las azofras, la documentación incluye prestaciones que no son en trabajo, pero que suponen un ingreso importante. Tal es el caso de la obligación de los mudéjares -más tarde de los moriscos- de abastecer la despensa señorial con productos francos o a precio de tasa para el consumo de la casa señorial; prioritariamente, gallinas, pollos, pollas, huevos, las uvas que quisiera el señor para comer él y sus acompañantes, siempre que fuese en tiempo de la cosecha; cabritos «pot pendre per a menjar uno un real», terneros «pot pendre un vedell per a sòn mejar uno per cinch souss», a condición de que el señor estuviese en el marquesado, con alguna excepción como el derecho de «llocada», que obligaba con un pollo cuando el señor lo requiriese, o por cuatro dineros, con independencia de la presencia del titular en el lugar.

Curiosamente, los mudéjares de Llombai no estaban gravados con esta azofra en el siglo XV, recogiendo en la relación de las rentas del XVI su puesta en vigor diciendo «pagen per lo nou dret los moriscats de Llombai per la obligació que tenen de

55. A.H.N.: Sección Osuna. Leg. 1.028. GOZÁLBEZ ESTEVE, E.: «Las azofras...», págs. 346 a 347.

56. A.H.N.: Sección Osuna. Leg. 1.028, fecha aproximada 1444. Ibíd.: Leg. 587/18. Concordia del año 1505 .

57. A.H.N.: Sección Osuna. Leg. 1.028. BENÍTEZ SÁNCHEZ-BLANCO, R. «Las cartas pucblas...», pág. 190 .

58. A.H.N.: Sección Osuna. Legs. 1.028 y 587/18. A.H.N.: Sección Osuna. Leg. 937. GOZÁLBEZ ESTEVE, E.: «Las azofras...», págs. 355 a 357 . LOPEZ ELUM, P.: «Carácter plurifuncional de la azofra». Anuario de estudios medievales. Barcelona $n^{\circ}$ 17, año 1987. págs. 193 a 206. 
donar al senyor a preu de tasa» siendo conmutada, acto seguido, por una aportación anual en efectivo ${ }^{59}$.

\section{f) Viajes en general}

Esta obligación consistía en realizar toda clase de mudanzas, transporte de correos, y acarreo de víveres tanto los provenientes de las particiones como las de otro origen.

La documentación manejada recoge este derecho en diferentes términos, lo cual induce a cierta confusión. Por ejemplo, cuando se habla de «adzembleria», se puntualiza que esta azofra afecta, exclusivamente, a los mudéjares de Alfarp, los cuales estaban obligados a acompañar al señor en sus viajes con sus «adzembles» insistiendo en que el señor debía hallarse presente, lo cual suponía que ningún oficial subalterno podía requerir este servicio. Por su parte, el señor se encargaba del mantenimiento del vasallo y de su cabalgadura abonándoles un sueldo diario. «Si lo senyor haura a fer viaje e aja abs adzembles son tenguts los moros de anar ab lo senyor present, lo senyor los ha a fer la messio els a dar ultra la messio delles e de la bestia un sou cascun jorn $\gg$.

A renglón seguido, el contrato agrario de mediados del siglo XV al que nos estamos refiriendo, recoge una importante modificación, suvizando la obligación a una tanda por heredad con animales y sin ellos, alternativamente, teniendo el señor que pagar si necesitase ampliar el servicio:

«con la aljama de Alfarp fos tenguda de anar ab besties o sens besties alla on lo senyor volgues franchs lo senyor los a feta gracia que no vol sino una tanda per heretat una $a b$ hestia e altra sens bestia, e si mes ne aura mester que'ls aja allogar axi com si fos estranger».

Sin lugar a dudas, en el señorío se mantuvieron las azofras tal y como fueron concebidas en su origen, o sea, como prestaciones en trabajo hasta finales del siglo XVI. Así consta en la documentación manejada «fer sofra» obligando universalmente a los mudéjares del señorío. En alguna ocasión, según las necesidades de su titular, se realizaban conjuntamente entre todos o parte de los vecinos, hasta que sucesivas concordias las fueron conmutando en imposiciones en metálico, tal como sucedió con la adzemblería. «Fonse avenguts ab mi la aljama de Alfarp per les tandes, que eren moltes, e els n'e fet gracia e aixi matex de la atzembleria navien de donar, fonse abenguts ab mi per tos tems e donen me tots anys quinze lliures e tenen-ne cartas"

A grandes rasgos, esta es la situación del señorío que nos ocupa en los siglos XV y XVI -soporte de dos comunidades con diferencias culturales, económicas, sociales y religiosas- en el cual, el hecho socio-político más destacable y que hipotéticamente podría haber aportado cambios sustanciales fue la Germanía.

La proximidad del marquesado a la villa de Alcira, localidad «agermanada» por excelencia, con una participación muy activa en este movimiento, hacía del señorío blanco idóneo; tanto por el apoyo que los cristianos viejos de Llombai podían prestar a los agermanados, como por el contraataque con que podía haber respondido el ma-

59. A.H.N.: Sección Osuna. Legs. 1.028, 722/6, 937 y 588/2.

60. A.H.N.: Sección Osuna. Leg. 1.028. 
yoritario núcleo mudéjar que allí residía. A estos factores hay que añadir otro muy decisivo: la pertenencia del marquesado al duque de Gandía, enemigo acérrimo de la Germanía.

Desgraciadamente, la documentación señorial en la que nos apoyamos sólo refleja una parte de la realidad, ya que las referencias que allí se recogen son, sencillamente, la rendición de cuentas de los subalternos señoriales; los cuales se excusan de haber entregado los graneros ante la dura presión de los agermanados, por lo que no es de extrañar que no nos consten datos sobre la coexistencia de estas dos comunidades en tan crítico momento, ni su participación activa en la contienda. Por otra parte, parece ser que este desconocimiento no es un caso aislado, ignorándose, sobre todo, la actitud de la comunidad islámica. Sebastián García Martínez, cuando habla de los lugares mudéjares cercanos a Alcira, se lamenta de que «aunque nada tenícm que hacer en el hando agermanado no tenemos datos de que intervinieron en el otro» ${ }^{\circ}$. Y Rafael Benítez, unos años después, sigue denunciando la falta de estudios sobre tan trascendental acontecimiento. Situación que trabajos posteriores como el realizado por Vicent Vallés i Borràs en Carlet, van subsanando ${ }^{62}$.

No obstante, pese al desconocimiento del fenómeno agermanado en el señorío, no podemos ignorar que el paso de la Germanía por él no fue, como la documentación señorial lo muestra, una mínima pérdida económica más anecdótica que importante ${ }^{\text {th. }}$. Muy al contrario fue un cambio decisivo, cargado de consecuencias, preludio de acontecimientos posteriores.

La comunidad islámica, al menos en los aspectos externos -al principio pausadamente y luego a ritmo cada vez más vivo- se tuvo que someter a nuevas restricciones. Analizando las franquicias comerciales concedidas en el señorío en el período 1521 a 1526, comprobamos que los mudéjares del señorío no fueron inmunes a esta nueva situación. Hasta el 1526 los mudéjares conservaron sus nombres árabes, sin embargo a partir de esa fecha los nombres cristianos son los que los identifican en la documentación oficial. Citemos como ejemplo, que cuando a Joan Bono se le da franquicia de «herrajes, peages...» se hace constar que su reciente bautismo le obliga a anteponer dicho nombre a su antiguo, «olim apellat Cabat Bono de Llombay» y algo similar sucede con Gabriel Cervello, » olim nomenat Masot Boiyat de Catadau $\gg$ y con Joan Marna del que se hace constar que «ans del bautisme era Mahomat Mar$n(c)$, entre otros muchos ${ }^{04}$.

61. GARCÍA MARTÍNEZ, S.: «La Ribera desce las Germanías a la expulsión de los moriscos». Economía crgrarici. Historia Local, Año I981, pág. 61 a 62.

62. BENÍTEZ SÁNCHEZ-BLANCO, R.: Las cartas pueblas..., pág. 193. VALLÉS I BORRÀS, V.: «Germanía y Señorí; la baronía de Carlet». A/-Gezira n 3. Año 1987, pags. 140 a 144. PINILLA PÉREZ, R.: «Crisis tras las Germanías en la morería de Alzira» Al-Gezira n ${ }^{\circ}$ 3. Revista d'Estudis Historics - Ribera Alta. Alcira, año 1987, pág. 125.

63. A.H.N.: Sección Osuna. Leg. 587/29. Proceso contra Luis Jofre. Año 1525. Apartado V1.

64. A.H.N.: Sección Osuna. Leg. 587/14. Franquicias de los años 1517-1522-1523-1526. CISCAR PALLARÉS. E. La Valddigna... «Sólo en 1573 el rigido y avaricioso Justicia Mayor Juan Galiana ordenaba que los moriscos no se llanasen por su nombre de moro, imponiendo una pena de diez días de carcel y diez sueldos para quien utilizase el nombre del linaje antes que el cristiano», pág 157. 
Con todo, no fue fácil borrar rasgos de identidad tan visibles como eran los nombres, apellidos y apodos, peculiaridades que, en la mayoría de los casos, ayudaban a delimitar una familia; por lo que, al menos para la administración interna, la pervivencia del árabe entre los moriscos del marquesado fue un hecho.

Las cuentas escritas por el Alamin de Llombai y Catadau en los años 1535-1539 registran los nombres propios de los vasallos siempre en árabe. Es de suponer que los moriscos entendían, y en algunos casos hablaban, el romance castellano o valenciano; no obstante el árabe es, en este documento, el idioma más importante, aunçue aparece a su lado, como traducción, un castellano con interferencias continuas del valenciano ${ }^{\text {ts }}$.

Sin ánimo de suplir lo que sólo una investigación más profunda sobre el tema nos puede aportar, conviene señalar que si en una época avanzada en el proceso de conversión (1535-1539), las aljamas del marquesado siguen escribiendo con grafía árabe -aunque sea en documentación tan cotidiana como la de registrar los jornales y todo lo concerniente a ellos- es porque en estas comunidades moriscas es aún el árabe, cocretamente la algarabía, la lengua predominante. De lo contrario, no tiene sentido, aun teniendo en cuenta que los alamines y los notables que componían las aljamas se esforzasen en conservar un signo distintivo tan importante como es el idioma ${ }^{66}$.

En cuanto a las mezquitas del marquesado, sufrieron la misma suerte que en los otros lugares valencianos. Del desmantelamiento de la mezquita de Catadau y utilización para otros fines, tenemos noticias muy concretas a través de las cuentas del arrendatario del año 1541. «Ha pagat dotze lliures XV sueldos en la despresa de lo çeller del oli que era primer mezquita, fet cals arena algeps y altres partiets y portes noves ${ }^{67}$.

A estos cambios, intrínsecamente relacionados con su cultura, costumbres y religión, hay que añadir un sinfín de consecuencias como las ocasionadas a raíz del paso del visitador inquisitorial Fray Bartolomé de los Ángeles por el marquesado (1528$1529)^{6.8}$.

Objetivamente, las anotaciones, que respecto a este señorío hace el religioso en su «cuaderno», son poco relevantes lo cual se puede interpretar de diversas formas. En primer lugar, que esto se debiera a una importante asimilación, situación poco probable entre otras razones porque la comunidad de la que se pretendía que perdiera su identidad era, en el señorío, numéricamente muy superior; en segundo lugar a una excelente simulación por parte de los moriscos, actitud que el Islam apoya plenamente ${ }^{(1)} ; \mathrm{y}$, en tercer lugar, a que la buena o al menos respetuosa convivencia de estos dos pueblos diese lugar a acusaciones aisladas y, por tanto, las intervenciones del Santo Oficio fuesen mínimas.

Esta última situación parece ser la más aceptable, ya que tan sólo dos denuncias fueron significativas: una denunciando una circuncisión, y otra contra Curdo, cristia-

65. A.H.N.: Sección Osuna. Leg. $587 / 53$.

66. A.H.N.: Sección Osuna. Leg. $587 / 53$.

67. A.H.N.: Sección Osuna. Leg. 937. Relación de las rentas del año 1541.

68. VIDAL BELTRÁN, E.: «El cuaderno de un visitador de moriscos Fray Bartolomé de los Ángeles». Estudis $n^{\prime \prime} 8$. Valencia, año 1979/80, págs 35 a 69.

69. HALPERIN DANGHI, T.: Un conflicto..., págs 136 a 145. 
no nuevo de profesión albardero, arrendatario de las cuatro carnicerías del marquesado, acusado de matar reses en Cuaresma, siendo sus delatores un cristiano viejo y un cristiano nuevo. Lo cual afianza la, ya apuntada, pacífica convivencia de estos dos colectivos.

Pero el cambio de coyuntura era un hecho y los moriscos, como respuesta a un vasto entramado de limitaciones y prohibiciones, se opusieron tenazmente a seguir gravados según los estatutos de los antiguos mudéjares ${ }^{70}$. Perceptiblemente, en el señorío, la carga fiscal seguía siendo discriminatoria. Sirva como ejemplo que en el arrendamiento del año 1530 se persiste en recordar que las azofras a las que estaban obligados los mudéjares continuaban vigentes para los moriscos.

A pesar de todo, se había producido un cambio y éste imponía la necesidad de nuevas normas fiscales acordes con la nueva situación; por lo que, en el citado arrendamiento, Don Francisco de Borja expone sus dudas respecto a si se deben disminuir algunas rentas a los moriscos en términos tan expresivos como que «se dubta que per ésser batejats e fets cristians los moros del present regne sien totes elevades e dismynü̈des algunes rendes, çofres, regalies e servituts de les que acostumen a pagar $e$ respondre» ${ }^{\prime 1}$. En esa tesitura, y quizá todavía pendiente de una resolución general para todo el reino, el duque de Gandía concertó con el arrendatario que si las rentas se quitaran o disminuyesen y dicha pérdida fuera menor de cincuenta libras, entonces «el señor respondería de lo que las rebajara» ${ }^{72}$.

Como era de esperar, este clima de incertidumbre y continuas reticencias, dio lugar a esporádicas rebajas a los nuevos convertidos, preferentemente en las particiones de frutos, siempre que acreditasen su actual situación, siendo muy estrictos en la aplicación de esta medida, como lo demuestra la negativa a que la viuda e hijos de Joan Centelles se beneficiasen de ella: Pretendían seguir pagando, como su esposo y padre, la décima parte de los frutos, insistiendo en que «fue gracia que se le concedió al convertirse» pero, al no presentar documentación que acreditase la legitimidad de la petición, se les notificó que debían pagar «como los otros moriscos» ${ }^{73}$. Realmente, fueron muy aisladas estas rebajas o cualquier otra actitud que igualase en la práctica la fiscalidad de estas dos comunidades en el marquesado.

Hemos de admitir que el planteamiento fue totalmente partidista. A los moriscos se les exigió con exceso y brusquedad que renunciasen a idioma, a costumbres, a religión..., demasiado para las pocas ventajas que obtuvieron de esta transformación, al menos externa, ya que insistimos que, aunque se dejaron bautizar y cerrar sus mezquitas, no hay que olvidar que un sinfín de conversiones fueron ficticias. Cardaillac dice al respecto que «frente a la presión que sobre ellos ejerce la política de asimila-

70. LÓPEZ DE COCA: «La fiscalidad mudéjar en el reino de Granada». V Simposio.... pág. 217. PERIS ALBENTOSA, T.-GIL SAURA, E.: «La difícil existencia de una comunidad marginal: Los moriscos Alcireños (1500-1616)». Cuadernos de trabajo n 5. Valencia, año 1986, págs. 69 a 91

71. A.H.N.: Sección Osuma. Leg. 587/32. Contrato de arrendamiento del año 1530.

72. A.H.N.: Sección Osuna. Leg. 587/32

73. A.H.N.: Sección Ostuna. Leg.594/17. 
ción de los reyes de España, optaron, por fingir, eludir y, en definitiva, organizarse en un cripto-Islam» ${ }^{74}$.

La clandestinidad era un precio que debían pagar y, así, lo hicieron; pero no estaban dispuestos a renunciar a las ventajas que pretendían sacar de su conversión. Esta confusa situación económico-religiosa contribuyó, ampliamente, a desnivelar el equilibrio de estos dos pueblos mientras conservaron sus religiones y se respetaron sus costumbres ${ }^{75}$.

El terreno se hallaba abonado para el desarrollo de un enfrentamiento. En el señorío, éste tuvo lugar a partir del año 1541, momento en el que el descontento, por parte, de los moriscos, se enconó, manifestándose en una persistente oposición a seguir siendo discriminados fiscalmente, negándose a pagar ciertos servicios personales, y también algunos censos. En el caso de estos últimos, los cristianos, en teoría, no siempre estaban libres de ellos; pero, en la práctica, sólo porque era costumbre, habían omitido obligaciones, tan inamovibles como las de carácter enfitéutico, como por ejemplo: los luismos.

Pero no sólo las diferencias eran fiscales, el alamín, como portavoz de la comunidad marginada, expuso una lista de quejas ante el titular del señorío de carácter socio-económico. Entre ellas, destacaban, las hechas contra el arrendatario, al que acusaba de negligencias intencionadas y de una insensibilidad fuera de lo común ya que ante la grave situación que atravesaba su pueblo, dice textualmente, «muriendo de hambre» se negó a auxiliarles, teniendo que ser él, el alamín, quien en repetidas ocasiones se viera obligado a entregar, en el momento de la siembra, la simiente necesaria a los miembros de su comunidad ${ }^{76}$.

Entre estas fricciones particulares y localizadas propias de cada señorío y los problemas comunes a todo el Reino de Valencia, el malestar de los moriscos se fue agudizando ante el desencanto de que su forzada conversión no les reportaba ninguna ventaja $^{77}$.

Con estas afirmaciones no estamos negando la existencia de semejanzas entre estos dos pueblos. Logicamente, después de tan larga convivenciia, era previsible que existiesen. Lo que aquí estamos cuestionando es el trato fiscal que ambas comunidades recibieron en atención a su diferente credo y su persistencia aún después de la conversión.

En el señorío, con frecuencia, las cuestiones económicas se antepusieron a las de otra índole; por tanto, no es de extrañar que el arrendatario formulase a su señor ciertas dudas muy significativas, entre las que hace notar que los moriscos parten los frutos al cuarto y los cristianos viejos sólo pagan diezmo y primicia; precisando que si un morisco vende una heredad a un cristiano viejo, no paga sino como cristiano, con lo cual las rentas disminuyen.

74. CARDAILLAC, L.: Moriscos y cristianos. Un enfrentamiento polémico. 1492-1640. Fondo de Cultura Económica, Madrid, año 1979, pág. 15.

75. GUINOT RODRÍGUEZ, E.: Cartes de Poblament Medievals Valencianes. Privilegios reales otorgados a los musulmanes de Eslida en el año 1404. Generalitat Valenciana, Valencia, año 1991, pág 660

76. A.H.N.: Sección Osuna. Leg. 594/17. Año 1541

77. A.H.N.: Sección Osuna. Leg. 594/17. 
La actitud acomodaticia del arrendatario y el vacío de normativas y disposiciones le llevó a plantear si lo que estaba gravado era la heredad o la persona, añadiendo que si un morisco compraba a un cristiano viejo, era la heredad lo que estaba gravado. «Y yo quiero conservar mis rentas con justicia y buena conciencia y deseo que vuestra señoría me informe en este caso de lo que en esto puedo hacer y si puedo hacer partir al cuarto a los cristianos que havieren mercado haciendas de los moriscos》s.

El apremio de liquidez y el temor a que los recursos disminuyesen, pero sobre todo la conflictividad del momento, determinó una respuesta ambigua por parte del señor, diciendo que se trataba de una cuestión muy delicada, pues: «habiéndose convertido los moros tiene necessidad de mirarse bien en ello por descargo de la conciencià. Consejo que debió ser desoído ya que las acusaciones y reproches de los moniscos hacia los representantes señoriales se incrementaron, concretamente, denunciaron al arrendatario de extorsión, ante lo cual el señor respondió amonestándole suavemente y advirtiéndole que «es conveniente que los moriscos no se vayan ni queden agraviados ${ }^{78}$.

Todas estas cuestiones denotan que, después de la conversión, las mejoras económicas fueron objeto de especulación; aunque, sobre todo, evidencian que los cristianos viejos aprovecharon las deserciones de los moriscos para ampliar sus patrimonios; de lo contrario, el arrendatario no hubiese presionado para que fuesen las tierras y no los hombres las que estuviesen gravadas.

En cuanto a las deserciones, era de suma importancia para el titular del señorío retener a sus vasallos moriscos en el lugar. No obstante el hecho de que éste diese ciertas muestras de deferencia hacia ellos; por ejemplo, concederles exiguas rebajas o mayor relevancia social, como la de requerir la presencia de un jurado de cada comunidad «lo hu cristià vell e lo altre moro segons ha manat la señoria se faja» ${ }^{74}$, cuando se tenían que justipreciar tierras señoriales, no era, ni mucho menos, suficiente para satisfacer a una población defraudada. Prueba de ello fueron los frecuentes abandonos del lugar registrados en la relación de las rentas del marquesado del año 1540 en las que constan las significativas penas impuestas a los que ayudaran a los moriscos a pasar a Berbería ${ }^{81}$, así como la retención de bienes a prófugos ${ }^{81}$.

Estos datos concretos, en última instancia, nos están informando de una situación cada vez más tensa y conflictiva entre los moriscos y los subordinados señoriales, todos ellos cristianos viejos; sin embargo, lamentablemente, no reflejan la relación entre estas dos comunidades en el ámbito personal y cotidiano.

Sin afán de sentar conclusiones definitivas, la documentación manejada refleja un trato desigual en cuanto a la fiscalidad, poniendo de manifiesto que tanto el duque

78. A.H.N.: Sección Osuna. Legs. 587 y 937/3. Relación de la renta del año 1540. Ibíd.: Leg. 594/17. Año 1541. GOZÁLBEZ ESTEVE, E.: Análisis de un señorio Valenciano..., págs. 297 a 298.

79. A.H.N.: Sección Osuna. Leg. 1.027. Año 1542.

80. A.H.N.: Sección Osuna. Leg. 937. Renta del año 1540. Ibíd.: Leg. 1.027. Relación de gastos del año 1538. Ibid.: Leg. 594/17.

81. A.H.N.: Sección Osunct. Leg. 594/17. Año 1541. PINILLA PÉREZ, R.: «Crisis tras la germania...», pág. 130. 
de Gandía como sus representantes, después de la forzosa conversión, se mostraron más permisivos respecto a las costumbres de los nuevos conversos, haciendo algunos esfuerzos para congraciarse con ellos, siempre que dicha actitud no afectase a sus ingresos.

Ahora bien, con independencia de otras motivaciones ya apuntadas, como la falta de disposiciones pertinentes, no debemos olvidar en ningún momento que la situación económica de la casa ducal, en la segunda mitad del siglo XVI, era más que precaria, y que el grueso de las rentas del señorío provenían de las particiones; las cuales, de forma real, sólo las soportaban los moriscos, al margen de otras contribuciones y servicios ya señalados; por lo que, en cierta forma, era lógico que el duque de Gandía no renunciase al importante ingreso que la comunidad de origen islámico le proporcionaba por su condición de inferioridad, aunque teóricamente pretendiese que esta condición estaba ya superada.

La polémica vida cotidiana entre estos dos pueblos, como apuntan Cardaillac, Hatperin Donghi, o García Cárcel, entre otros ${ }^{82}$, no es posible que pueda aplicarse indiscriminadamente para las ciudades y para el medio rural, pues en éste unos y otros tenían, necesariamente, que avenirse para convivir.

Por tanto, no es superfluo recordar que la ubicación en el señorío de ambas comunidades y el reducido número de cristianos viejos potenció la conservación de las costumbres e identidad de la comunidad sometida; pero, también, una dependencia mutua entre estos colectivos en materia de agricultura, construcción, comercio y demás servicios. Así lo indican numerosas citas como que el único herrero de Llombai fuese el alamín ${ }^{\times 3}$, o que el morisco arrendatario de las carnicerías fuese, además, el albardero del lugar ${ }^{* 4}$, por citar algunos ejemplos.

Esta realidad, ineludiblemente, propiciaba unas relaciones de vecindad que quizá el tiempo fue reforzando. Afirmación siempre condicionada a que posteriores y más profundas investigaciones sobre el tema, como es nuestra intención realizar, no nos demuestren lo contrario.

No obstante, la coexistencia de estos dos pueblos debió ser compleja. El mero hecho de ser una la comunidad dirigente y otra la sometida era razón más que suficiente para que existiesen mutuas desconfianzas, como así sucedió, agudizándose ese sentir a partir de la forzosa conversión. Después de este acontecimiento, ninguna de las dos comunidades se debió llevar a engaño, fundamentalmente en materia religiosa. A los ojos de los arrendatarios y de otros cargos administrativos, los moriscos, pocas veces, fueron nombrados como cristianos nuevos. Excepcionalmente, en alguna ocasión, se les cita como «moriscats»; pero, habitualmente continuaron siendo «moros», denominación similar a «infiel», que evidencia que su identidad y distinto ori-

82. CARDAILLAC. L.: Moriscos y Cristianos: Un enfrentamiento... págs. 15 a 16 . HALPERIN DONGHI, T.: Un conflicto..., pag. 53, GARCÍA CARCEL. R.: «La historiografia sobre los moriscos españoles. Aproximación a un estudio de la cuestión». Estudis Valencia n" 6. Año 1977, págs. 83 y 89.

83. A.H.N.: Sección Osuna, Leg. 587. El alamín ejercía el oficio de herrero.

84. VIDAL BELTRÁN, E.: «El cuaderno...», págs. 35 a 69. 
gen no se olvidó nunca. Así lo recoge la documentación referente a la administración local, aun en comentarios en los que se pretende darles cierta relevancia ${ }^{85}$.

El peligro que representaban los moriscos estuvo siempre presente generando todo tipo de medidas represivas tales como el superficial desarme del año $1525^{\mathrm{g}}$, o el más riguroso del año $1563^{87}$. El resultado de ambos, en el marquesado, fue el hallazgo de un importante número de armas ofensivas, sobre todo, en el último. Por tanto no es de extrañar que el clima de desconfianza trascendiera a la vida cotidiana, generalizándose el recelo entre ambas comunidades e, inevitablemente, distanciándolas. Sirva de ejemplo la acusación que formulan los cristianos viejos contra el baile por mostrar cierta preferencia hacia los vasallos moriscos como vigilantes del marquesado, alertando al señor en los siguientes términos: «si el baile los pone serún tres moriscos con tres acas y para el tiempo que corre vuestra senyoría puede pensar lo que se puede fiar de un morisco» añadiendo que la tranquilidad del lugar y la pacífica convivencia de sus moradores hacía innecesaria su presencia ${ }^{88}$.

En cuanto a la marginalidad de los moriscos, a tenor de sus propiedades, no podemos afirmar que la tierra que poseían en el marquesado fuese peor que la que tenían los cristianos viejos. Nos inclinamos a pensar que la descompensación económica no provenía tanto de que sus tierras fuesen de mejor o peor calidad, o más o menos extensas que las que tenían los cristianos viejos, tema ampliamente debatido por historiadores como Ciscar Pallarés, Ardit Lucas, o La Parra López, sino, más bien, por una fiscalidad muy diferente para unos y otros ${ }^{81}$.

Cabe añadir que en el caso concreto del marquesado de Llombai, si en un primer momento hubo desigualdades en cuanto a extensión o calidad, con el paso de los años se debieron ir borrando ya que durante siglos se potenció la venta de tierras a mudéjares o moriscos, como líneas atrás hemos apuntado ${ }^{*}$.

La estructura socio-económica de los mudéjares, más tarde de los moriscos ha sido un tema preferente entre los historiadores. Para una gran mayoría de ellos, esta comunidad era una minoría pobre y desorganizada sujeta a mayores cargas y medidas represivas, pero estudios recientes, suavizan y relativizan estos términos. Dentro de esta línea están Ciscar Pallarés, Vallés Borrás, Peris Albentosa, Benítez SánchezBlanco, Hinojosa Montalvo, con excelentes estudios globales y locales sobre el reino de Valencia. Con similar criterio, se definen Pascual Ortega cuando analiza la situación de los mudéjares catalanes; Laredo Quesada, en relación a los castellanos y Ló-

85. A.H.N.: Sección Osuna. Leg. 1.027. Año 1542. CISCAR PALLARÉS, E.: La Valldigna..., pág. 158.

86. VALLÉS I BORRÀS, V.: «Germanía y Señorío...», pág. 145

87. A.R.V.: Sección Real Chancillería. Leg. 562.

88. A.H.N.: Sección Osuna. Leg. 588/37. CISCAR PALLARÉS, E.: La Valldigna..., pág. 218.

89 CISCAR PALLARÉS, E.: Tierra y señorío..., págs. 67 y 105. ARDIT LUCAS, M.: «Expulsió dels moriscos i creixement agrari al País Valenciàs. Afers 5/6. Valencia, año 1987, pág. 299. LA PARRA LÓPEZ, S.: «iMoros y cristianos en la vida cotidiana: historia de una represión sistemática o de una Convivencia frustrada? $\gg$. Anales $n^{\circ} / 1$, Alicante, año 1992, págs. 160 a 161.

90. A.H.N.: Sección Osuna. Leg. 1.028. Contratos agrarios 1444. Los mudéjares estaban gravados con un pago suplementario en la alcaydía. "Si vendía ningun moro heretat ab casa paga sis sous de alcaydia e s'is vendra sens casa tres sous'». 
pez de Coca Castañer, referente a los granadinos; por traer a colación algunos ejemplos".

Como es lógico esta vertiente tiene sus detractores, básicamente, entre historiadores cuya investigación local les demuestra lo contrario. Entre ellos, nos interesa destacar a La Parra López, tanto por su magnífico estudio sobre las relaciones existentes entre cristianos y moriscos en el ducado de Gandía como por el hecho de la dependencia del marquesado al mismo señor, con la salvedad que Gandía, en donde el investigador centra sus estudios, es una ciudad y nosotros estamos hablando de una comunidad rural $^{92}$. Aunque hemos de reconocer que estudiosos del medio rural, ya citados, como Benítez Sánchez Blanco al analizar la fiscalidad de Benimamet, o Ciscar Pallarés en su brillante y exhaustivo análisis de La Valldigna no observan tampoco ninguna diferencia entre el gravamen que pesa sobre los mayoritarios moriscos y los cristianos viejos ${ }^{13}$.

Ahora bien, señalado este planteamiento, no está de más recordar que, para valorar el peso de la presión fiscal, es necesario distinguir siempre entre la teoría y la realidad, ya que como antes hemos indicado, en el marquesado de Llombai, la costumbre regía y se apartaba con el paso del tiempo del punto inicial, o sea de las cartaspueblas y de los contratos agrarios, beneficiando principalmente a los cristianos viejos ${ }^{94}$. Pero es muy difícil precisar si en la práctica los mudéjares-moriscos cumplieron con las obligaciones que estos documentos recogen. Por sus quejas y reticencias, parece ser que sí. Por tanto, en nuestro caso, podemos aplicar las palabras de Cardaillac cuando dice que los moriscos cargados con severas particiones y duras obligaciones, como eran las azofras, fueron forzados a una conversión que, aunque no deseada, les hizo abrigar esperanzas de mejoras económicas que les igualase con los cristianos viejos; esperanzas que se vieron defraudadas, debido, fundamentalmente, a la actitud de sus señores ${ }^{95}$. Actitud que puso de relieve la doble intencionalidad señorial, que hacía inviable esa igualdad porque se pretendía asimilar a los moriscos al cuerpo de la nación cristiano-valenciana sin alterar la estructura social del reino que se apoyaba en una división jerarquizada entre cristianos viejos y moriscos.

91. CISCAR PALLARÉS, E.: Tierra y señorío... págs. 105 a 123. VALLÉS I BORRÀS, V.: «Germanía y señorio...», pág. 137. BENÍTEZ SANCHEZ-BLANCO, R.: «Las cartas pueblas...», pág. 190 a 193. HINOJOSA MONTALVO, J.: «Señorío y fiscalidad mudejar en el Reino de Valencia». V Simposio..., pag. 105. ORTEGA PASCUAL, P.: «La fiscalidad mudejar en Cataluña». V Simposio.... pag. 171. LADERO QUESADA, M.A.: Los mudéjares de Castilla en la Baja Edad Media. Universidad de Granada. Granada, año 1989, págs. 60 a 67. LÓPEZ DE COCA CASTAÑER, J.E.: «La fiscalidad mudejar en el Reino de Granada». V Simposio..., pág. 191.

92. LA PARRA LÓPEZ, S.: «La fiscalidad mudéjar en el ducado de Gandía: El ducat de foc». V Simposio..., págs. 265 a 267.

93. BENÍTEZ SÁNCHEZ-BLANCO, R.: «Benimamet: Una baronía en la huerta de Valencia a finales del siglo XVI». V Simposio..., pág. 261. CISCAR PALLARÉS, E.: La Valldigna..., pág. 157 a 160.

94. GOZÁLBEZ ESTEVE, E.: Análisis de un señorio..., págs. 167 a 184. A.H.N.: Sección Osuna. Legs. $937 / 3,594 / 17$ y 1.028 .

95. BORONAT Y BARRACHINA, P.: Los moriscos españoles y su expulsión. Estudio Histórico-Crítico. Imp. Francisco Vices y Mora, Valencia, año 1901. Vol. I. pag. 539. 
Por último, cabe insistir, una vez más, que nuestra intención ha sido esbozar principalmente las diferencias existentes entre la tributación que soportaban los cristianos, los mudéjares y los moriscos del marquesado. La conclusión que extraemos de este breve análisis es que la comunidad de origen islámico, tanto antes como después de su forzosa conversión, estuvo sometida a mayores exigencias que la de los cristianos viejos de Llombai y de la mayoría de los lugares vecinos.

Pese a todo lo expuesto, somos conscientes de no haber agotado el tema, queda pendiente explorar otros fondos documentales, tratar cuestiones que aquí no hemos incluido y, por supuesto, profundizar en torno a los planteamientos aquí debatidos. 